\title{
Building value-driven HRM practices in Western Multinational Enterprise in Ghana using the AMO model
}

\author{
THEOPHILUS AZUNGA ${ }^{1}$, ADOMBILLA BABA BLONCH ${ }^{2}$ and ABURIYA A. DIANA ${ }^{3}$
}

1. THEOPHILUS AZUNGA, Department of Management Studies, Bolgatanga Polytechnic, Box 767, Bolgatanga, Ghana

2. BABA BLONCH ADOMBILLA, Department of Management Studies, Bolgatanga Polytechnic, Box 767 , Bolgatanga, Ghana

3. DIANA A. ABURIYA, Department of Management Studies, Bolgatanga Polytechnic, Box 767, Bolgatanga, Ghana

\begin{abstract}
Despite the increasing presence of Western MNEs' subsidiaries in Ghana, the country continues to remain underrepresented in international human resource management literature (IHRM). The purpose of this research is to address this lacuna by examining recruitment and selection; training and development; performance management; rewards management and employee communication and participation using the ability, motivation and opportunities (AMO) model to build value-driven human resource management (HRM) practices in Western MNEs in Ghana. The paper employs a qualitative multiple case study approach using semi-structured interviews with employees and managers in purposefully selected Western subsidiaries in Ghana. This research employs 37 in-depth interviews with managers and employees in eight British, European and US MNEs in Ghana. The study essentially provides fine-grained analysis of how subsidiaries develop strategies in each HRM practice to promote employee ability, motivation and opportunity (AMO) and possibly organisational performance.
\end{abstract}

Keywords: HRM practices, Multinational Enterprise in Ghana, AMO model

DOI: $10.7176 / \mathrm{JRDM} / 53-07$

Publication date:March $31^{\text {st }} 2019$

\section{Introduction}

Organisational practice is an essential capability considered crucial for MNEs with high interdependence between HQs and subsidiaries (Klimkeit and Reihlen, 2016). Transfer of organisational practice enables MNEs to take advantage of the opportunities in every local context, particularly in countries where skills and expertise are lacking. MNEs can derive the benefits accruing from the host contexts and subsidiaries can as well benefit from resources from corporate HQ. MNEs from developed countries often claim their management and technical skills are superior to those of their counterparts in developing countries (Chang et al., 2009; Chung et al., 2014), particularly in Africa where talent and effective work practices are deficient (Asiedu, 2004; Kamoche et al., 2012). With particular reference to Ghana, Barthel et al. (2011) noted that foreign firms expressed concerns about the low productivity of the labour force and shortage of technical and managerial skills. These findings coincide with Akorsu and Cooke (2011) where Chinese MNEs gave the same reason for importing Chinese labour into Ghana. These observations may lead to MNEs transferring HRM practices from their home economies that they have successfully implemented before and which they believe are suitable for the subsidiary context (Dickmann and Muller-Camen, 2006).

The Ghanaian cultural and institutional specifics diverge significantly from the West. Nonetheless, corporate HQs of Western MNEs put considerable pressure on their subsidiaries to adopt HRM practices of HQ which are deemed financially competitive and superior to those of host context (see Thite et al., 2012). For example, in Ghana and in many other African countries, the cultural rules of the game based on tribalism, in-group collectivism, corruption, religious and spiritual orientations, patriarchy and patrimony (Wanasika et al., 2011) tend to influence recruitment and selection; training and development; performance management; and rewards management, worklife balance and employee communication and participation. Kuada (2010) raises the possibility that collectivism in Africa, and in Ghana, is more akin to a form of familism (i.e., loyalty to the maintenance and functioning of the family or tribal unit). Senior managers are likely to put family and personal interests first, ethnic interest second and corporate interests third (Wanasika et al., 2011). The cultural rules of the game that tend to favour members of an in-group in terms of HR practices are likely to foster organisational ineffectiveness, inefficiency and low productivity (Zoogah et al., 2015). Yet another cultural characteristic is the influence of deeply held feelings of in-group loyalties (or expectations). Such feelings can lead to leaders and managers acting benevolent to some yet dismissive of others (Kuada, 2010; Wanasika et al., 2011).Western MNEs regard their own HRM practices as 
"best practices" which are claimed to work efficiently and also circumvent the possibility of duplicating effort and time in experimenting with other unfamiliar HRM practices (Geary et al., 2017). According to Osabutey et al. (2014: 564) foreign firms in Ghana usually have superior resources and expertise and as a result are likely to impose ethnocentric HRM practices in their subsidiaries (Kamoche and Newenham-Kahindi, 2012). They may thus perceive Ghanaian HRM practices as inferior and seek to transplant their HRM practices with a strong belief of superiority.

This research chooses Ghana as the focus of this study because it is the sixth-largest recipient of FDI in Africa and second in West Africa (Ernst and Young, 2015; UNCTAD, 2013). The growth in FDI is significant for this study because of the associated expansion of employment opportunities (GIPC, 2016) and the probable transfer of HRM practices. Kehl (2007) classified Ghana alongside nine other African countries (Botswana, Cape Verde, Ghana, Lesotho, Mauritania, Mauritius, Namibia, South Africa and Swaziland) as emerging economies. The country advanced to lower middle income status in 2011, with relatively strong democratic institutions, discoveries of oil and gas, and an economic growth rate of eight percent $(8 \%)$ per annum, leading to significant attraction of FDI (GIPC, 2013; IMF, 2013). According to Sutton and Kpentey (2012: 1), "Ghana has been one of Africa's fastest growing economies over the past decade." Due to the stable institutional environment and the growth of FDI, there has been a corresponding increase in employment (GIPC, 2013). ). Regardless of the fact that research on HRM and management in Africa is growing (Aryee, 2004; Budhwar and Debrah, 2001; Jackson, 2004; Kamoche et al., 2015), "there is a significant paucity of empirical research on HRM [...] in European and US firms" (Horwitz, 2015). Horwitz (2015) further emphasised that besides the paucity of research, there is shallowness of literature of western MNEs in Africa. In addition to this, Kamoche et al. (2012) observed that the extant literature on Africa has systematically portrayed Western management practices as incompatible with the African context. This research contributes to the paucity of research on HRM practices in examining how Western MNEs build valuedriven practices using employee AMO. The paper seeks to contextualise its findings by responding to issues of contextual effects on HRM practices in an underrepresented context in the IHRM literature, by asking: Why do Western MNEs standardise HRM practices in their subsidiaries in Ghana? How can standardised practices contribute to MNE success through strategic utilization of employees' abilities, motivation and opportunities? This research demonstrates that despite local Ghanaian cultural pressures of in-group favouritism, tribalism, nepotism and familism - loyalty to the maintenance and functioning of the family, Western MNEs are "rational, and self-interested actors" Jackson and Deeg, 2008: 545) able to act according to their preferences. The study therefore seeks to enhance an understanding of these issues from an under-researched and new geographical context (Budhwar and Debrah, 2001; Kamoche et al., 2012). The paper is structured as follows: Issues in the existing literature about cross-border transfer of HRM practices are discussed. This is followed by introducing the abilities, motivation and opportunities (AMO) framework as the chosen theoretical tool for the study. The methods, results and discussion are then presented. The paper concludes with specifying the research contributions, practical implications, limitations of the study, and future research directions. The research explains via the AMO framework how managers can achieve MNEs' strategic goals through HR practices that are skill-enhancing, motivation-enhancing and opportunity enhancing. HR practices that promote employee abilities, motivations and opportunities may influence business gains in terms of productivity, quality, service, safety and financial returns.

\section{Cross-border transfer of HRM practices}

Western MNEs usually endeavour to transfer HRM practices to their subsidiaries in developing countries using an ethnocentric approach (Siebers et al., 2015). These practices are usually embedded in the parent country's values, assumptions and norms (Muller, 1998). They perceive the HRM practices of corporate HQs to be well developed, validated and superior to the indigenous practices of developing countries (Arthur et al., 1995; Thite et al., 2012). Following this argument, my motivation is to examine how successfully Western MNEs implement value-driven HRM practices using the AMO in their subsidiaries in Ghana

A key component of a country's social context is its normative institutions. It is envisaged that a large institutional distance between the host and parent country of an MNE constrains the transfer of organisational practices (Eden and Miller, 2004; Kostova and Zaheer, 1999). Kostova and Zaheer, (1999) maintain that the larger the institutional distance between the host and parent country of the MNE, the more difficult it is to establish legitimacy or to transfer a practice from the parent company of an MNE to a subsidiary. Gaining legitimacy both within an MNE and externally in a host country is crucial for successful operations (Xu et al., 2004).

The difficulty of establishing legitimacy or transferring a practice is attributable to the fact that organisation structures and practices tend to mirror the institutional environments in which they were nurtured (Kogut, 1993). Legitimacy evolves as a result of a congruence of values between an MNE and society (Parsons, 1960) and "the 
degree of cultural support for an organisation" (Meyer and Scott, 1983:201). Suchman (1995: 555) concludes that organisations gain legitimacy by implementing practices deemed "desirable, proper or appropriate within some socially constructed system of norms, values, beliefs and definitions." Transferred HRM practices may be deemed legitimate in line with what Gyekye (2014: 181) argued that, "it would be correct to say that there is no human culture that has remained the same ever since it was created, neither has there been a system of cultural values impervious to influences from outside and, thus, untouched by values from other cultures."

Subsidiaries of Western MNEs usually implement the following HRM practices in line with those of their corporate headquarters (HQ): recruitment and selection; training and development; performance management; rewards management; work and life balance; employee communication and participation. For instance, to ensure that HRM practices of subsidiaries align with those of $\mathrm{HQ}$, expatriates and former inpatriates who are familiar with HQ routines are used to train local employees to ensure that subsidiary work practices conform to HQ (see Sarabi et al., 2017). The deployment of these HRM practices to subsidiaries facilitates the coordination and control of HRM practices and the institutionalisation of a common corporate culture (Edwards et al., 2007).

\section{Abilities, Motivation and Opportunities (AMO) model}

HRM can generate high value for an organization through having skilled, committed and empowered employees (Kaufman, 2015). Ability, motivation, opportunity (AMO) theory suggests that effective employee performance is a function of the abilities, motivation and opportunity to engage in discretionary behaviours towards the achievement of an organisation's strategic goals (Appebaum et al., 2000). Thus, it is argued that recruitment and selection have some bearing on ability by ensuring that capable employees are employed in the first instance, and capping with training, learning and development. Motivation can be influenced by extrinsic (e.g. financial) and intrinsic rewards (e.g. interesting work) performance reviews, feedback, and work- life balance. Opportunity can be influenced by communication, involvement initiatives, team working, and autonomy (Trošt et al., 2016).

Employers have to create the necessary opportunities for employees to use their skills. HRM practices are expected to enhance employee skills and motivation which in turn are likely to affect the productivity, quality, service and financial outcomes of an organization. Skill enhancing practices influence performance by improving human capital (Knowledge, skills, abilities), while motivation and opportunity enhancing practices increase performance by enhancing employee attitudes and commitment (see Jiang et al., 2012; Boon, Eckardt, Lepak, and Boselie, 2018). Jiang et al. (2012) observed that HRM enhances organizational performance by: creating a valuable human capital pool; and promoting preferred employee behaviours.

Thus it is argued that in order to ensure that an organization has employees with requisite skills, organizations embark on rigorous recruitment and selection and training and development practices to ensure abilities are acquired to ensure performance as well as motivation-enhancing performance strategies that include performance management, competitive compensation, incentives and rewards, and benefits (Jiang et al., 2012). It is also important to ensure that as well as employees having the required abilities and opportunities to utilize them to perform, that motivation of employees is linked to the performance of strategically important tasks. Thus, managers should clearly define and communicate work assignments and give regular feedback to employees (Buller and McEvoy, 2012). Opportunity- enhancing performance strategies include teamwork, employee involvement and information sharing (Jiang et al., 2012). Organisational policies should allow employees to engage in "flexible and discretionary behaviors that help the organization achieve its strategic goals in a dynamic business environment" (Buller and McEvoy, 2012: 51). It is necessary for employees to have the requisite knowledge, skills and abilities and the motivation to utilize these in routine performance for the benefit of an organization. We now discuss the research methods for this study.

\section{Methods}

Ghana is a country and a context which has been underrepresented in academic research in business and management more broadly and international HRM specifically. In order to make an important contribution to the understanding of the nature of human resource management in MNEs in Ghana, it would be desirable to avoid hypothesising relationships between variables in a context with several unexplored issues relating to HRM, until qualitative research can bring more clarity into the understanding of the key concepts related to this complex process (Azungah et al., 2018). Edmondson and McManus (2007) rightly point out that using a quantitative approach to study a phenomenon in a new context is likely to yield little learning from a study. This is because the measures are likely not to be directly related with the phenomenon under investigation. It is proposed that doing research in emerging markets requires qualitative research, since some instruments developed and used in the developed markets may not be readily applicable in emerging market settings (Hoskisson et al., 2000; Zhao et al., 2005). Detailed, rich and evocative data are needed to shed light (Edmonson and McManus, 2007) on the transfer 
of HRM practices as an important, yet not well understood phenomenon in the Ghanaian context. As a result, the paper adopts a narrative style with emphasis on the crucial role of focal actors (Cornelissen, 2017) such as former inpatriates, Regional HQ managers, expatriates, employees, HCNs in the standardisation of HRM practices. Using semi-structured interviews, this research draws on 37 face-to-face interviews with subsidiary managers and employees in eight companies from May to July 2015 which lasted on average about one hour per interview. For reasons of confidentiality, pseudonyms are employed in place of real names. The subsidiaries are coded as USA1, USA2 for American companies; UK1, UK2, UK3 for British companies; F1 for French, S1 for Swiss and G1 for the German company. Companies were chosen consistent with Stake (1995) that selected cases should be where learning is greatest. The choice of countries of subsidiaries namely the United States, France, United Kingdom, Switzerland and Germany is informed by the fact that these countries were among the top ten countries with the highest number of registered projects in Ghana in 2014 (GIPC, 2014). Interview informants included HR director, Area manager, HR managers and employees of participating companies. All interviewees were fluent in English because it is used as the international business language in the subsidiaries. Consequently, all interviews were conducted in English. Interviews were recorded only when participants consented. However, as Hutchings (2004: 143) notes "tape-recording interview notes has been considered de rigueur for modern research" but in my research, not all participants were prepared to have their interviews recorded. Five participants refused to be recorded. In such a situation, the researcher listened attentively and took notes at the same time. Then, in order to minimise the richness of data loss, as soon as the interview was over, he quickly typed the notes and emailed them to the interviewee to authenticate. In all cases these emails were sent, participants made corrections and additions to the texts.

Using interviews as data collection techniques helps address cultural insensitivity "as the African is more willing to provide information through oral narration, traditional way of imparting and sharing knowledge, than having to answer structured questions that include writing and experimentation" (Oppong, 2017: 15). Also, the prospects of verifying information from previous interviews with other interviewees are made possible in semi-structured interviews (Bryman and Bell, 2015), which further enhances credibility of the findings. In addition to the interview guides, information for this study was also obtained from company bulletins, brochures and flyers.

\section{Data analysis}

The research employed both deductive and inductive approaches in analysing the data. The deductive approach uses a framework, often described as a start list (Miles and Huberman, 1994)., On the other hand, the inductive approach, according to Thomas (2006: 238), refers to "approaches that primarily use detailed readings of raw data to derive concepts and themes." It involves reading data line by line thoroughly and assigning codes to paragraphs or segments of texts as concepts unfold (Bradley et al., 2007; Curry et al., 2009) relevant to the research questions (Thomas, 2006). It is an iterative process that involves moving back and forth between data analysis and the literature to make meaning out of evolving concepts (Neeley and Dumas, 2016).

Also, in order to minimise the incidence of personal bias and enhance the trustworthiness/rigour of the analyses (Burnard et al., 2008; Miles and Huberman, 1994; Pope et al., 2000), another researcher, checked the coding schemes. He posed critical questions about the data analysis processes which helped in refining the analysis (Lauckner et al., 2012).

\section{Findings}

MNEs standardise HRM practices in their subsidiaries based on the features of universalism, where job vacancies are filled based on merit. Recruitment and selection practices are targeted at attracting the best candidates. Selected candidates undergo training and other socialisation activities which enable them to understand and work with corporate values. Employees use these corporate values to accomplish their tasks. MNEs use attractive reward packages that facilitate employee acceptance of these corporate values. Communication between management and employees is done through unions, committees and town halls. The research identifies and summarises key characteristics of HRM practices in Western MNEs in Table 1. The characteristics of the following HRM practices that are utilised in subsidiaries of Western MNEs in Ghana are derived from the corporate HQs. 
Table 2.3: Characteristics of HRM practices in subsidiaries

\begin{tabular}{|l|l|}
\hline Standardisation & Characteristics of practices \\
\hline Recruitment and Selection & $\begin{array}{l}\text { Poaching, company websites, interviews and } \\
\text { tests at HQ or host country based on potential, } \\
\text { skills, competencies, establishing talent pools }\end{array}$ \\
\hline Training and development & $\begin{array}{l}\text { Content developed at HQ, training at HQ, use of } \\
\text { inpatriates, experts from Regional HQ, use of } \\
\text { expatriates. }\end{array}$ \\
\hline Performance management & Content derived HQ and deemed transparent \\
\hline Rewards management & Contingency rewards based on targets \\
\hline
\end{tabular}

\section{Recruitment and selection}

The eight subsidiaries use funnel approaches to filter from the large pool of job applicants in order to arrive at best-fit for roles. The funnel approach which refers to the steps in recruitment and selection practices entails inviting a large pool of job applicants and selecting the best. Seven subsidiaries often advertise vacant positions through their company portals which can enable them recruit persons with specialised skills from all parts of the country and beyond. Job applicants in all subsidiaries are usually required to sit an aptitude test. According to another employee of UK1, "You write a series of tests and if you pass, you are short-listed and you go through an interview" (AbaUK1-Mketing Mger). Subsidiaries embark on rigorous recruitment and hiring of persons with the best KSAs and not based on favoritism or social group membership. The rigorous recruitment practices provide subsidiaries with new skills to carry out required tasks.

Additionally, job candidates who pass the test have to attend interviews. At executive level, job candidates are sometimes interviewed at the global corporate HQs. For instance, in the American extractive company USA1, executive level job candidates are sent to Denver where they undergo several screening interviews. This extractive company also executes a distinctive recruitment and selection process called opportunistic hiring. The HR Manager explains that

We do what we call opportunistic hiring, which is before the position becomes vacant, if we know we don't have an internal candidate, we start to profile people. Let's say, Mine Manager, we know we don't have an internal candidate, we profile all the mine managers in Ghana to know who the best is. We actually go and talk to the person and ask if he/she is interested in a particular role" (BiyarUSA1-HR Mger).

Interviews, both at the subsidiary and corporate level, are meant to ensure that candidates possess the job attributes considered success factors by MNE control standards. These are control mechanisms put in place to determine membership of the corporate family. Tests and interviews are also considered standardised procedures in formalising HRM practices at subsidiaries. Although tests and interviews are also used in indigenous organisations for recruitment and selection, an interviewee revealed that "some persons are recruited into certain roles not based on their performance at the test or interview" (AlorUK3-Emp).

Furthermore, outstanding employees are put on a career plan. The employee is intermittently evaluated to determine whether he/she is fulfilling certain roles, taking on additional responsibilities or acting successfully in certain roles when his/her superior is not there. The HR Manager for the French bank F1 corroborates with the above arguments stating that

Some local companies do not care who comes to fill their role. They do not keep a talent pool, without knowing that if you keep a talent pool, and there is a vacancy, you do not need too much time to push the person there or to help that person to be able to fit that role, forgetting that if the person is not able to fit the role earlier, productivity will suffer and it will have direct impact on the cash flow. This is because the time you are supposed to use to get the job done, you are training the person or somebody is virtually leaving his/her job to help that person do his work (BertoFl-HR Mger).

Subsidiary USA2, the American courier licensee, has no succession plans in place. A possible explanation is that all the directors are Ghanaians. Vacant positions are therefore likely to be filled not based on competence but on 'whom you know.' Any suggestion to management about having succession plans in place is likely to be interpreted to mean wanting the downfall of a superior; which can trigger animosity in the work environment. The 
lack of succession planning in such circumstances can lead to inability to take certain strategic decisions in the event of strategic positions such as chief executive position becoming vacant.

\section{Training and development}

Subsidiary training and development programmes are designed to enhance the knowledge, skills, and abilities of employees through a systematic employee training needs analysis in order to effectively deliver and manage the process. Some of these training programmes include the HQ manuals and instructions, training materials online, and employee identification with corporate MNE. The Human Resource (HR) Manager of USA2 observed that "The content of our training comes from our head office. There is a manual that we use and it is revised every year. When it is revised, the managers are called for training at the regional HQ" (MulkaUSA2-HR Mger). Training programmes are also technology based and an employee explains that "We have online training sessions. We have compulsory ones and depending on the department you work with, they have other suggested training you can do" (OnoahG1-Emp). These technology based trainings are meant to enhance greater efficiency, convenience for trainees, and decrease costs compared to traditional training methods.

Additionally, subsidiaries use prolonged induction and specialists from both the Regional and Corporate HQs in their training, aimed at ensuring that employees learn corporate values. With the exception of the French bank F1 which does not have Regional HQ in Africa, all the other subsidiaries benefit from specialist services from their respective regional HQs. The HR Director for the British beverage manufacturer UK2, points out

We have an HR Director for Africa who sits in South Africa with specialists such as talent management specialists, compensation specialist, industrial relations specialist and organisational development specialist. So all these people are there and they provide services to us and even if you want them to visit your country, they will and they do it. We have our own way of training our sales, marketing, technical and human resource people. So, most of the content comes from the Regional hub because there are specialists who sit there and their work is to develop all these things" (TurayUK2-HR Director).

Specialists from the global corporate office also visit subsidiaries to train employees in new programmes and technology. Employees and managers imbibe the values and beliefs of MNE and are likely to engage in cooperative and committed behaviours towards the achievement of corporate goals. These corporate trainers further enhance the coordination, monitoring and control of subsidiary HRM practices to align with HQ.

Corporate HQ sometimes engages consultants to train employees. For instance, the HQ of USA1 had contracted a consultant to conduct training on inclusive leadership. The HR Manager explains that it is "a company that is known to train people to become more inclusive, so from a global level we contracted that company and they are the ones going across all our regions to do that training" (BiyarUSA 1-Emp). Corporate HQ officials as well as consultants visit subsidiaries and conduct training which aimed at integrating subsidiary HRM practices to parent company practices.

Prolonged induction training also enables new employees to build corporate identity by sharing the values, vision, mission and goals of subsidiaries. Induction training allows new employees to understand the processes, systems, mission and vision and the strategic direction of subsidiaries. The HR Manager of the British detergent manufacturer UK1, reveals that "when we employ new graduates, we take them through a training programme, for a maximum of two years but sometimes it is shortened", depending on individual performance. At the American mining company, new employees are placed in the Learning and Development Department for three months to learn theoretical and practical aspects of the jobs. They also learn the values and behaviours necessary to work effectively within the subsidiary. Ability enhancing skills focus on buying skills and enhancing those of existing employees. Western subsidiaries also use performance management to configure subsidiary goals with those at HQ.

\section{Performance management}

Performance management serves as a vehicle for achieving corporate and subsidiary goals. MNE performance targets are communicated to subsidiaries with criteria to be used to achieve them.

Staff are evaluated twice yearly - mid and end of year. Objectives with key performance indicators known as operational and behavioural objectives are set at the beginning of the year to monitor and guide employee actions. The operational objectives are linked to the strategic direction of the business and the targets for each department are usually spelt out. Heads of departments sit with their teams to agree on individual targets. "You have to meet your targets using company values" (MayUK3-Emp). Therefore, "the 'what' refers to what you have to do and it covers $60 \%$ and 'how' refers to how you achieve the targets using company values and it takes $40 \%$. For instance, 
your target may be excellent customer service which is the 'what' and 'how' may be by respecting the customer" (SantanaUK3-Emp). Though, the American courier licensee does have performance goals cascaded from its regional hub in Dubai, there seemed to be no detailed system in place for performance management. The HR Manager reveals that "we ask the departmental heads to do the assessment on yearly basis and then they report to the HR department. There is a template sent to them to do the appraisal" (MulkaUSA2-HR Mger). The other seven subsidiaries have elaborate electronic systems in place to track performance against targets. Performance management is associated with bonuses, salary increments and promotion to align employee work output to corporate goals. Corporate HQ values are entrenched in performance management practices at subsidiaries to guide behaviours and actions of employees.

Employees are divided in their opinion about the merits of performance management practices. Some are of the opinion that it is good, fair, transparent and objective, while others feel that it makes them overwork and they are unable to take their full entitlement of annual leave. Employees at UK2 and S1 resisted strongly the implementation of performance management, but management's decision prevailed. The HR Manager at UK2 explained that "initially there was resistance here and there", (IsaUK2-HR Mger) whilst an employee at S1 also noted that for the bi-yearly appraisals

We are not use to this but either you stay or jump out. If not because of unemployment in the country, we would have left because their policies are not suitable but some have already left because everyone would love to work in a relaxed environment (RalfS1-Emp).

The HR Manager of UK2 indicated, "If it is coming from the hub, you have no option than to implement for instance the performance management" (IsaUK2-HR Mger). The procedure of appraising employees is a product of the parent companies with little input from subsidiaries.

Assessments of employees in all subsidiaries are based on what they agreed with their heads of departments to do from the beginning of the year against what they have been able to do at the end of the year. A manager of the French bank F1 explains

Hitherto, performance appraisal was subject to whims and caprices of supervisors and managers before the acquisition. Now, no one can cheat any person since it is objectively and scientifically recorded using online platforms. The system is able to tell how far you have gone, what you are doing, so they look at your targets and then they give a particular mark to it" (JoFl-Mger).

Based on these targets, there is a midyear review and end of year appraisal. Motivation of employees is promoted through performance management practices. Employees should be motivated and to carry out strategically important tasks. As a result, employee's routine tasks should be clearly defined, communicated with regular feedback given on performance. Additionally, rewards should be linked to achievement of targets.

\section{Rewards management}

Rewards (sometimes referred to as compensation and benefits in some contexts) are both financial and nonfinancial. Financial rewards are key mechanisms for attracting, motivating, retaining employees and enhancing performance. By making certain rewards such as variable pay and bonuses, contingent upon satisfactory performance, MNEs are able to align HRM practices at subsidiaries with those at HQ. Reward packages differ from one subsidiary to another, with a focus on attracting and retaining best talented employees and fostering their commitment and loyalty to subsidiary goals. Wage and salary increment rely on negotiations between unions and management in companies USA1, UK2, UK3, and F1. In other subsidiaries such as USA2, UK1, G1 and S1, committees negotiate on behalf of employees. In the German courier G1 for instance, the HR Manager explains that "we compare salaries with the market to see where we stand and to ensure that we are always competitive" (FramG1-HR Mger). However, USA1 is a distinctive case where salaries of employees are indexed to the United States of America (USA) dollar (USD). An employee claims that "the main salary is indexed to the USA dollar because of the instability of the Ghanaian cedi (currency), employees negotiated with management through their unions and the salary was indexed to the dollar" (JonaUSA1-Emp).

However, despite the existence of unions and their influence on salary scales, salary increases are dependent on individual performance. The HR Director for the beverage manufacturing firm UK2 points out

Pay is based on the achievement of performance targets that one can either get an increment or not. Before the acquisition, at the beginning of the year unions negotiated for salary increments and everybody gets. But now you can only get these monies increased by way of your hard work. There is no free lunch anywhere" (TurayUK2-HR Director). 
The HR Manager for UK1 explained that "salary is performance-related and employees with good performance receive higher salary." Company website sources also emphasised that it is "operating a multicultural meritocracy, in which individual employee contribution is compensated' (UK1 company web sources). Financial rewards of employees and managers are linked directly with individual performance. Through appropriate rewards, the firm creates the belief among employees that greater efforts will pay off, which nurtures employees' willingness to be proactive in their tasks.

Additionally, employees of USA1, UK1, UK2, and G1 are paid thirteen times in a year. There is an annual bonus which is tied to individual performance at USA1, UK1, UK2, UK3, F1, and G1. Two participants at F1 concurred that a bonus is given to "everybody but it cuts across at a certain percentage" (MakiF1-Emp). A percentage is "the same for everybody and another percentage is based on the individual performance. The individual range is bigger than the group bonus" (NilieF1-Emp). The variable bonus process is transparent, based on whether an individual employee has met his/her performance targets or not. The Marketing Manager of UK1 explains, "If you yourself have written that missed target and they didn't give you that bonus, you shouldn't be angry because the process is transparent. We don't have issues on that" (AbaUK1-Mketing Mger). Corporate assessment criteria devoid of personal biases are used to track employee performance in line with HQ goals.

Also, with the exception of the American Licensee USA2, the British bank UK3 and the Swiss oil company S1, employees in the other subsidiaries are paid allowances when going on annual leave. MNEs use financial rewards to control performance and enhance commitment towards global corporate strategic goals.

The components of rewards are least in the American Licensee USA2 and the HR Manager argued, "it is the directors who do their own thing" (MulkaUSA2-HR Mger). This implies that the placement of individual employees within the salary range is not consistently applied, with some employees put on a lower scale, whilst others are put on a higher notch, probably without commensurate skills, qualifications and experience.

Paternity leave, which is rare in Ghana, is offered by USA1 and UK3 and G1 for a period of ten paid days. An interesting finding at USA1 is that there is a safety bonus of 5\% of employee salary. Employees are given $100 \%$ of this bonus if no injuries or accidents occur in a month. However, the desire to get the bonus leads employees to conceal the reality of the number of accidents because "even a small cut and you report it to management, the whole bonus is cancelled" (GonaUSA1-Emp). As a result, minor accidents are not reported. This mining company also provides free lunch for its employees, while lunch is subsidised or monthly allowances are paid to employees in the other subsidiaries. The two British manufacturing companies, UK1 and UK2 in household consumables and alcoholic and non-alcoholic beverages, provide their employees with free company products monthly. The French bank F1 gave shares to its full time employees in 2010. Thus, all financial and non-financial rewards are targeted at motivating employees and managers towards accomplishing corporate HQ strategic goals.

Employee communication and participation refers to employees being involved in issues that affect them in the workplace and it differs across the subsidiaries. Employees are unionised in USA1, UK2, UK3 and F1. The nature of USA2 as a licensee also limits HQ control on its HRM practices. Subsidiaries also organise town hall meetings. According to the HR Manager of the American gold mine subsidiary USA1, "Town halls are done across the business globally. They are open fora where management shares information with employees on the strategic direction of the business and employees are given opportunities to ask questions or provide their opinions" (BiyarUSA1-HR Mger). In the British bank UK3 likewise, the senior management/executives of the bank hold durbars (formal meetings) with employees. Town hall meetings and durbars are held in all subsidiaries except S1. Information sharing practices can help employees to align their behaviour with subsidiary goals, policies and regulations to carry out their tasks.

In addition to town hall meetings, subsidiaries such as USA1, UK1 and F1 have instituted on-line platforms called employee barometer surveys, where employees are anonymously allowed to freely express their opinions about the organisation, including its HRM practices. An independent organisation collates and analyses these questionnaires, sending the results to their respective HQs. Issues of concern are addressed and employees are subsequently informed of actions taken. Employee barometer surveys as part of consultative mechanisms are utilised to test the pulse of employees on new practices or to advise employees on certain HRM practices. They are useful means of ensuring that employees are integrated within the MNE corporate culture.

Additionally, the American subsidiary USA1 and the British manufacturer UK1 have instituted speak-up policies. UK1 has operationalised an anonymous telephone service that employees can use to report their concerns, while 
USA1 has a policy in place to safeguard employees to speak up on issues of concern. A participant at USA1 notes that:

They have something called speak up, whatever bothers your mind you have to come out with it. I can say it is a policy because it is there for us to speak up what is not going on well. There is speak up team. If something is bothering your mind about the work (CharlieUSA1-Emp).

However, HR Manager of UK1 explained that employees rarely used this speak-up policy. A possible explanation is that employees are less likely to use such facilities in a power distance context to express their grievances. Another possible explanation is that they are not sure if their identities will be leaked to their superiors. Nonetheless, providing employees with opportunities to participate in decision-making on work and organisational outcomes boosts morale and confidence and promotes autonomy in their task performances.

\section{Efficiency and competition}

Subsidiaries standardise their HRM practices to achieve efficiency. Standardisation helps to increase operational efficiencies "by identifying, cutting and keeping tab on operational expenses" (F1 website sources). Subsidiaries engage agency workers and contract workers as part of cost cutting measures and to achieve operational efficiency.

Work practices in the host context might have also be deemed to be ineffective. For instance an employee of F1 explains that before acquisition "we were doing the conventional way of practices and procedures. You sit down and a customer will come, you will not bother yourself calling a customer to come for a loan because whether a customer comes or not, at the end of the month you will be paid. But these days, your performance is used to judge you" (MakiFl-Emp). Transferred HRM practices are believed to be sources of concerted effort, efficiency and competitive advantage for subsidiaries.

A thorough analysis of and in-depth understanding of the local context help USA1 standardise its HRM practices because "if you just go ahead and standardize, you will not be able to meet those challenges that you cannot standardise" (BiyarUSA1-HR Mger). Subsidiaries are able to standardise their HRM practices more effectively, once they know the local context.

\section{Sustainability}

Also, according to some of the participants, corporate HQ values serve as the bedrock for sustainable businesses in all companies. An employee in UK3 observes that "the basic things in UK3 are our values. Our values are respect, service, integrity, excellence and stewardship" (MayaUK3-Emp). Documentary sources corroborate this assertion, stating that the company's values "are fundamental to UK3 long-term success and represent the set of standards under which all of us at UK3 will work...we know that only a business driven by strong values can deliver strong sustainable returns" (UK3 web sources). These values are universal and are communicated through company flyers and websites, with the intention of promoting a corporate mind-set. MNE values determine how the goals of subsidiaries are achieved. The Marketing Manager of UK1 explains "we don't have people that are not pulling their weight staying in this company for two, three years. No, you will be out. So everybody strives to uphold the company values" (AbaB1-HR Mger). MNEs use corporate values to communicate their goals and the appropriate conducts for the compliance of employees in subsidiaries.

In pursuance of maintaining viable businesses, subsidiaries transplant HRM practices they believe are core and are sources of competitive advantage. Explaining the experience of implementing performance management in the subsidiary, the HR Manager of UK2 reveals that

The unions realise that, from the beginning there are people who will do a good job and others can't do a good one and they expect to share the same thing with you. If you do that, you are not making the environment very competitive, you are not ensuring that there is positive competition among people. In that way productivity suffers (IsaUK2-HR Mger).

Subsidiaries standardise HRM practices to ensure fairness and productivity.

\section{Transfer of staff between roles}

Subsidiaries UK1, UK2, UK3, G1 and S1 standardise their HRM practices to "ensure that within the group everybody stays on the same knowledge level so that if they need to move you around within roles or move you to a different station you are capable" (EtoG1-Emp). Western MNEs transfer their HRM practices to the Ghanaian context towards ensuring consistency in the management of employees globally in terms of corporate work processes, systems and procedures to facilitate the movement of staff across roles. 
Explaining further, an employee notes that transfer of practices is done

Because of the cross fertilization we don't have to go too much off the mark. If you train somebody on different software and a position becomes vacant say in South Africa and you have to deploy the person to South Africa, the person should not find it difficult to execute a similar role. So they are more similar" (RobertiS1-HR Mger).

Nonetheless, an employee of S1 observed that corporate HQ practices are imposed on them by stating that "here, you have the strategy of the investor, his culture is this is the way I implement my practices. You either fit in or you drop out" (RoyS1-Emp).

\section{Discussion of findings}

Western MNEs succeed in transferring their preferred HRM practices to Ghana in order to achieve corporate strategic goals, irrespective of the cultural and institutional challenges. They have relatively standardised HRM practices which are embedded in western values in their subsidiaries and as such can be regarded as adopting an ethnocentric approach. An ethnocentric strategy refers to the replication of HRM practices that are consistent with the assumptions, beliefs, expectations and values of the cultural and institutional environments of an MNE's home country (Myloni et al., 2004). The beliefs hold that western countries are more advanced technologically and economically than Ghana, coupled with a postcolonial perception of the "inferiority of African administrative systems" (Kiggundu, 1991: 34) which provide the rationale for utilising practices transferred from HQ and which reflecting an ethnocentric ethos. Western MNEs standardise their HRM practices in Ghana for the principal purposes of efficiency and effectiveness, sustainability and transfer of staff between roles and between different countries.

Subsidiaries use recruitment and selection practices that are relevant to task performance, by filling vacancies with high-performing employees assessed for appropriate knowledge, skills and competencies. They offer wage premiums to attract and retain talented employees. The Ghanaian job market lacks experienced, professional, technical and managerial staff, largely due to the mismatch between the needs of industry and the skills graduates acquire from tertiary institutions (Osabutey and Debrah, 2012; Osabutey, 2013). Nonetheless, it is possible that hiring of persons using company portals may deny persons in rural communities who are likely to have computer anxiety and less internet access at home. The shortage of skills in the host context to meet the efficiency expectations of MNEs leads to competitive hiring strategies. Current employees who have demonstrated potential and, who are regarded as star performers, are also recruited to fill existing vacancies.

With regards to training and development, the findings suggest that subsidiaries are investing heavily in training and development programmes based on needs analysis. Corporate HQ uses induction training to socialise new employees to corporate culture. Employees learn new developments using online training platforms which serve to integrate subsidiaries to MNEs. It is however possible that local employees who are relationship-oriented may prefer interactive-based approaches to training via groups than information technology. Corporate HQ ensures that subsidiary employees learn and acquire the values, beliefs and behaviours necessary to carry out their work assignments in line with corporate HQ expectations. Training needs are determined from employee performance outcomes. Training initiatives contribute to enhancing the skills of employees (Beltrán-Martín and Bou-Llusar, 2018), which relates to the "make" and "buy" approaches to improve employees' KSAs (knowledge, skills and abilities). Furthermore, some of the content of training and development practices of subsidiaries emanate from corporate HQs with limited or no input from the local context (see Mamman et al., 2009; Michailova and Hollinshead, 2011) to specify the type of competencies required for certain tasks. These findings support earlier research that subsidiaries use training and development to improve employees' skills, knowledge and abilities in order to work effectively and to compete favourably with their competitors (Boselie et al., 2005; Rosenzweig and Nohria, 1994).

Performance management practices focus on individual task performance. Individual performance is acknowledged and compensated. Training programs, which are designed to improve employees' skills and knowledge, can be reinforced by developing motivation-enhancing practices that promote recognition of employees' contributions. Performance management is instrumental in identifying individual weaknesses in task performance in order to put in place corrective action which is essential in career planning and development. This finding supports past research that performance management serves as the basis for organisational resources to be distributed to business units and employees (Aguinis, 2013, Evans et al., 2011) and to enhance subsidiary efficient 
and effective performance. The content and processes of performance management practices are derived from corporate HQ.

Nevertheless, unlike previous research which has shown that subsidiary managers have made adjustments to employee evaluations because the performance management criteria were considered too high for the host context, and in order to maintain group harmony (see Yahiaoui, 2015), some employees in this current research complained of targets being too high but nonetheless accepted the individual nature of the assessment. The findings are also contrary to the notion that employees in collectivist contexts usually prefer to be assessed in groups (Aycan, 2005; Satorius et al., 2011). Aycan (2005) observed that positive feedback for individual employee performance could spark jealousy and bitterness in collectivist cultures and as a result disrupt group disharmony. However, employees regarded the individual-based assessment as fair, transparent and objective, unlike the host context practices which tend to be ad hoc and subjective (as has been previously suggested by Debrah, 2001; Ohemeng, 2009). A possible explanation for the findings is that employees in the Ghanaian context might not necessarily be opposed to individual target-based performance management practices, provided that the criteria are seen to be transparent and objective. It is when performance management criteria are not explicit, with much discretion given to management to assess employees that resistance to individual performance management arises, probably due to suspicion that some employees will be favoured to the disadvantage of others. The findings further support Gyekye's (1988: 31-32) assertion that African societies exhibit features of both individualism and collectivism, which he describes as amphibious in order "to avoid the excesses of the two exaggerated systems." It may therefore be a misjudgement to categorise individuals within a particular country as individualist or collectivist, because people have different opinions, values, interpretations and attitudes that are not stagnant (McSweeney, 2002), which suggests that individualism and collectivism are on a continuum meaning values change over time. Another possible explanation for this finding is that the high costs of living associated with urbanisation promote individualism in the cities unlike in the rural areas where collectivism is readily practiced.

The findings also reveal that rewards management practices align with MNE corporate HQ practices. An employee either receives an increment in pay or a high bonus based on the achievement of targets. The individual-based assessment is usually regarded as fair, transparent, and objective, devoid of discriminatory practices that can create tensions in the work environment and affect the work and financial outcomes of a subsidiary. This finding concurs with the findings of Tayeb (1998), that financial compensation of subsidiaries is a control mechanism to monitor financial operations of affiliates in line with corporate strategic goals. Employees of subsidiaries are also in a position to understand what is expected of them and to compare their performance to clearly defined criteria, unlike the host context practices which tend to be based on favouritism and subjectivity (Debrah, 2001; Ohemeng, 2009).

In line with past research, subsidiaries implement work-life balance programmes that include paternity leave, flextime and shifts to allow some time off (see Nickson et al., 2004) in order to improve quality of work and life. Organisations introduce work-life balance programmes to enable them to retain skilled workers, reduce absenteeism, increase productivity, efficiency and financial performance. This finding supports previous studies that work-life balance programmes enable employees to focus better at work, reduce conflict and turnover in the work place and improve their physical and mental well-being (Alegre and Pasamar, 2017; Cegarra-Navarro et al., 2016). Work-life balance programmes are intended to brand subsidiaries as welcoming and suitable places to work and to differentiate these work-places from their competitors. Paternity leave, flex-time and shifts are a rarity in the Ghanaian context and are obviously derived from the corporate HQs of the subsidiaries.

However, contrary to the findings of Kamoche and Newenham-Kahindi (2012: 2868) where local employees complained about CitiBank's social activities such as swimming, walking, jogging and other sports as they considered them to be for children and an "intrusion into their private lives", employees in the current study supported and participated in these work/life balance programmes. This could be attributed to publicised health education programmes in the Ghanaian media and health talks organised (for the general populace) by professional bodies such as the Ghana Health Service. Another possible explanation behind this finding is the rapid urbanisation of the cities and the influence of western media. For instance, it is common to see on the cities' roads at weekends various keep-fit clubs engaged in physical exercise.

Employee communication and participation practices equally conform to HQ practices to a certain degree. Some subsidiaries avoid trade unions and collective bargaining agreements with employees. Muller (1998) argues that western MNEs usually have a unitarist perspective and are anti-unions both in their home countries and in their subsidiaries. Employees are seen to belong to a single team with common goals and values with no barriers to communication. In a power distance context such as Ghana, a non-unionised work environment is likely to limit employees' participation because workers fear individually expressing their views or dissent. Employees would prefer to do that in a group; most preferably through unions. As a result, there is likely to be limited resistance to 
transferred practices in non-unionised work places. Western MNEs prefer giving information directly to employees unmediated through unions (Croucher et al., 2014). Communicating directly with employees is meant to provide opportunities for workers to speak up on matters concerning HRM practices without fear of individually focused reprisal. It is anticipated that participation will also grant employees the opportunity to be involved in decisionmaking procedures and to exercise some level of influence on issues in the subsidiaries (Michailova, 2002). Participation can probably increase the level of innovativeness and initiation on the part of employees in subsidiaries. Employee communication and participation practices reflect the relatively low power distance, and the egalitarian nature of the cultural and institutional contexts of Western MNEs. Subsidiaries convene regular meetings with employees through town hall fora and also conduct attitude surveys to assess their practices. These communication channels serve as grounds for concrete decision-making (Muratbekova-Touron, 2008). However, Abugre (2013) explains that employees in Ghana find it difficult to communicate directly with their superiors because most managers consider employees with divergent views to be nonconformist. Open fora are likely to be less effective in high power contexts because managers are less receptive to divergent opinions and employees are equally afraid to speak their minds to management. At best, these fora serve as sources of dissemination of information by management rather than reflecting participatory decision-making.

\section{Implications for research and practice}

This research contributes to the scholarly conversation on how subsidiaries implement ability, motivation and opportunity enhancing HRM practices to ensure that appropriately skilled, motivated are empowered to use their skills and motivation to achieve organisational goals in a high power distance context. The paper explains how subsidiary investments in recruitment and selection, training and development, performance management, rewards management, work and life balance as well as employee communication and participation are likely to improve the knowledge, skills, abilities, motivation as well as provision of opportunities to employees to participate decision-making. Thus, implementation of the AMO model tends to promote morale, team spirit and participative partnership of employees (Obeidat, 2016) in subsidiaries of Western MNEs.

The AMO model applied in this research can help inform organizations and managers on how to effectively enhance employee KSAs, provide supportive work environment and motivation through continuous learning, training, feedback and appropriate remuneration to enable employees deploy their capabilities effectively towards the achievement of subsidiary strategic goals.

Nevertheless, this research is not without limitations. The paper employs cross-sectional data which were collected at the same point of time. Future research could adopt a longitudinal approach in order to provide detailed knowledge and understanding on how consistent employee attitudes and behaviours may be enabled by recruitment and selection, training and development, performance management, reward management, work and life balance and employee communication and participation.

A practical contribution of this research is that it may also allow local Ghanaian companies to compare their HRM practices with those prevalent in western countries. Gyekye (2014: 181) argued, "it would be correct to say that there is no human culture that has remained the same ever since it was created, neither has there been a system of cultural values impervious to influences from outside and, thus, untouched by values from other cultures." Ghanaian companies may be in a position to learn and adapt certain foreign HRM practices to their organisations whilst there is also the possibility for foreign MNEs to learn from Ghanaian practices and transfer them to subsidiaries in other countries.

\section{Acknowledgement}

We thank our colleagues from the Bolgatanga Polytechnic who provided insight and expertise that greatly assisted this work. Also, all references are duly acknowledged.

\section{References}

Abugre, J. B. (2013). Current and desired employee communication patterns in sub-Saharan Africa: Empirical evidence on four Ghanaian organizations. Journal of African Business, 14(1), 33-46.

Aguinis, H. (2013). Performance Management. Upper Saddle River, NJ: Prentice Hall.

Akorsu, A. D., and Cooke, F. L. (2011). Labour standards application among Chinese and Indian firms in Ghana: typical or atypical? The International Journal of Human Resource Management, 22(13), 2730-2748. 
Alegre, J., and Pasamar, S. (2018). Firm innovativeness and work-life balance. Technology Analysis and Strategic Management, 30(4), 421-433.

Appelbaum, E., Bailey, T., Berg, P. and Kalleberg, A.L. (2000), Manufacturing Advantage: Why HighPerformance Work Systems Pay Off, ILR Press, Ithaca, NY.

Arthur Jr, W., Woehr, D. J., Akande, A., and Strong, M. H. (1995). Human resource management in West Africa: Practices and perceptions. International Journal of Human Resource Management, 6(2), 347-367.

Aryee, S., (2004) 'HRM in Ghana'. In Kamoche, K., Debrah, Y.A., Horwitz, F.M. and Muuka, G.N. (eds) Managing Human Resources in Africa. London: Routledge, pp. 121-34.

Asiedu, E. (2004). The determinants of employment of affiliates of US multinational enterprises in Africa. Development Policy Review, 22(4), 371-379.

Aycan, Z. (2005). The interplay between cultural and institutional/structural contingencies in human resource management practices. The International Journal of Human Resource Management, 16(7), 1083-1119.

Azungah, T. Michailova, S. Hutchings, K. (2018) "Embracing localization: evidence from Western MNEs in Ghana", Cross Cultural and Strategic Management, https://doi.org/10.1108/

Barthel, F., Busse, M., and Osei, R. (2011). The characteristics and determinants of FDI in Ghana. European Journal of Development Research, 23(3), 389-408.

Beltrán-Martín, I., and Bou-Llusar, J. C. (2018). Examining the intermediate role of employee abilities, motivation and opportunities to participate in the relationship between HR bundles and employee performance. $B R Q$ Business Research Quarterly, 21(2), 99-110.

Boon, C., Eckardt, R., Lepak, D. P., and Boselie, P. (2018). Integrating strategic human capital and strategic human resource management. The International Journal of Human Resource Management, 29(1), 34-67.

Boselie, P., Dietz, G., and Boon, C. (2005). Commonalities and contradictions in HRM and performance research. Human Resource Management Journal, 15(3), 67-94.

Bradley, E. H., Curry, L. A., and Devers, K. J. (2007). Qualitative data analysis for health services research: developing taxonomy, themes, and theory. Health Services Research, 42(4), 1758-1772.

Bryman, A. and Bell, E. (2015), Business Research Methods, Oxford University Press, Oxford.

Budhwar, P.S., and Debrah, Y.A. (Eds.). (2001). Human Resource Management in Developing Countries, Routledge, UK.

Buller, P.F. and McEvoy, G.M. (2012), "Strategy, human resource management and performance: sharpening line of sight", Human Resource Management Review, Vol. 22 No. 1, pp. 43-56.

Burnard, P., Gill, P., Stewart, K., Treasure, E. and Chadwick, B. (2008), "Analysing and presenting qualitative data", British Dental Journal, Vol. 204 No. 8, pp. 429-432.

CCSM-08-2017-0093

Cegarra-Navarro, J. G., Sánchez-Vidal, M. E., and Cegarra-Leiva, D. (2016). Linking unlearning with work-life balance: an initial empirical investigation into SMEs. Journal of Small Business Management, 54(1), 373 391.

Chang, Y. Y., Mellahi, K., and Wilkinson, A. (2009). Control of subsidiaries of MNCs from emerging economies in developed countries: the case of Taiwanese MNCs in the UK. The International Journal of Human Resource Management, 20(1), 75-95.

Chung, C., Sparrow, P., and Bozkurt, O. (2014). South Korean MNEs' international HRM approach: Hybridization of global standards and local practices. Journal of World Business, 49(4), 549-559.

Cornelissen, J. (2017). Editor's comments: Developing propositions, a process model, or a typology? Addressing the challenges of writing theory without a boilerplate. Academy of Management Review, Vol. 42 No. 1, pp. 1-9.

Croucher, R., Rizov, M., Goolaup, R. (2014). The antecedents of direct management communication to employees in Mauritius. The International Journal of Human Resource Management, 25(17), 2420-2437.

Curry, L. A., Nembhard, I. M., and Bradley, E. H. (2009). Qualitative and mixed methods provide unique contributions to outcomes research. Circulation, 119(10), 1442-1452.

Debrah, Y. (2001). Human resources management in Ghana. In Budhwar, P.S., \& Debrah, Y.A. (eds). Human Resource Management in Developing Countries, pp. 190-208. London: Routledge.

Dickmann, M., and Muller-Camen, M. (2006). A typology of international human resource management strategies and processes. The International Journal of Human Resource Management, 17(4), 580-601.

Eden, L., and Miller, S. (2004). Distance matters: Liability of foreignness, institutional distance and ownership strategy. In Hitt, M. and Cheng, J. (Eds.). Advances in International Management. Pp. 187-221. New York, NY: Elsevier.

Edmondson, A. C., and McManus, S. E. (2007). Methodological fit in management field research. Academy of Management Review, 32(4), 1246-1264. 
Edwards, T., Colling, T., and Ferner, A. (2007). Conceptual approaches to the transfer of employment practices in multinational companies: an integrated approach. Human Resource Management Journal, 17(3), 201217.

Ernst and Young (2015). EY's Africa attractiveness survey: Africa 2015: Making choices. Available at: www.ey.com/.../EY-africa-attractiveness-survey-2015.../EY-africa-attract. access 13 September 2015.

Evans, P., Pucik, V., and Björkman, I. (2011). Global performance management. In Evans, P., Pucik, V., and Björkman, I. (Eds.). The Global Challenge: International Human Resource Management. pp. 346-390. New York, NY: McGraw-Hill.

Ghana Investment Promotion Centre. (GIPC). (2013). Third Quarter Report, (9)3. Accra, Ghana. Available at: www.gipcghana.com/press.../11-2013.html?...2013-investment-report. Accessed 18 December 2014.

Ghana Investment Promotion Centre. (GIPC). (2014). Second Quarter Report, (10)2. Accra, Ghana. Available at: www.gipcghana.com/press.../11-2013.html?...2013-investment-report accessed. 30 December, 2016.

Geary, J., Aguzzoli, R., \& Lengler, J. (2017). The Transfer of 'International Best Practice' in a Brazilian MNC: A Consideration of the Convergence and Contingency Perspectives. Journal of International Management, 23(2), 194-207.

Gyekye, K. (2014). Philosophy Culture and Vision: African Perspectives: Selected Essays. Sub-Saharan Publishers, Ghana.

Horwitz, F. (2015), "Human resources management in multinational companies in Africa: a systematic literature review", The International Journal of Human Resource Management, Vol. 26 No. 21, pp. 2786-2809.

Hoskisson, R. E., Eden, L., Lau, C. M., and Wright, M. (2000). Strategy in emerging economies. Academy of Management Journal, 43(3), 249-267.

Hutchings, K. (2004). Behind the bamboo curtain: problems and pitfalls in researching Australian expatriates in China. In Clark, E. and Michailova, S. (Eds.). Fieldwork in Transforming Societies. Understanding Methodology from Experience. 136-156. London: Palgrave Macmillan.

IMF (2013). IMF Country Report, Ghana. No. 13/187. Washington, D.C http://www.imf.org/external/pubs/ft/scr/2013/cr13187.pdf Accessed 28th April, 2015.

Jackson, G., and Deeg, R. (2008). Comparing capitalisms: Understanding institutional diversity and its implications for international business. Journal of International Business Studies, 39(4), 540-561.

Jackson, T. (2004). Management and Change in Africa: A Cross-cultural Perspective. London: Routledge.

Jiang, K., Lepak, D.P., Hu, J. and Baer, J.C. (2012), "How does human resource management influence organizational outcomes? A meta-analytic investigation of mediating mechanisms", Academy of Management Journal, Vol. 55 No. 6, pp. 1264-1294.

Kamoche, K., and Newenham-Kahindi, A. (2012). Knowledge appropriation and HRM: the MNC experience in Tanzania. The International Journal of Human Resource Management, 23(14), 2854-2873.

Kamoche, K., Chizema, A., Mellahi, K., and Newenham-Kahindi, A. (2012). New directions in the management of human resources in Africa. The International Journal of Human Resource Management, 23(14), 28252834.

Kamoche, K., Siebers, L. Q., Mamman, A., and Newenham-Kahindi, A. (2015). The dynamics of managing people in the diverse cultural and institutional context of Africa. Personnel Review, 44(3), 330-345.

Kaufman, B. E. (2015). Evolution of strategic HRM as seen through two founding books: A 30th anniversary perspective on development of the field. Human Resource Management, 54(3), 389-407.

Kehl, J. R. (2007). Emerging markets in Africa. African Journal of Political Science and International Relations, 1(1), 001-008.

Kehl, J. R. (2007). Emerging markets in Africa. African Journal of Political Science and International Relations, 1(1), 001-008.

Kiggundu, M. N. (1991). The challenges of management development in sub-Saharan Africa. Journal of Management Development, 10(6), 32-47.

Klimkeit, D., and Reihlen, M. (2016). Organizational practice transfer within a transnational professional service firm: the role of leadership and control. The International Journal of Human Resource Management, 27(8), 850-875.

Kogut, B. (1993). Learning, or the importance of being inert: Country imprinting and international competition. In Ghoshal, S., and Westney, D. E. (Eds.), Organization Theory and the Multinational Corporation. Pp. 136-154. New York: St. Martin's Press.

Kostova, T., and Zaheer, S. (1999). Organisational legitimacy under conditions of complexity: The case of the multinational enterprise. Academy of Management Review, 24(1), 64-81.

Kuada, J. (2010), "Culture and leadership in Africa: a conceptual model and research agenda", African Journal of Economic and Management Studies, Vol. 1 No. 1, pp. 9-24. 
Lauckner, H., Paterson, M., and Krupa, T. (2012). Using Constructivist Case Study Methodology to Understand Community Development Processes: Proposed Methodological Questions to Guide the Research Process. The Qualitative Report, 17(13), 1-22.

Mamman, A., Baydoun, N., and Adeoye, B. (2009). Transferability of management innovation to Africa: A study of two multinational companies' performance management system in Nigeria. Global Business Review, 10(1), 1-31.

McSweeney, B. (2002). Hofstede's model of national cultural differences and their consequences: A triumph of faith-a failure of analysis. Human Relations, 55(1), 89-118.

Meyer, J. W., and Scott, W. R. (1983). Organisational Environments: Ritual and Rationality. Beverly Hills, CA: Sage.

Michailova, S. (2002). When common sense becomes uncommon: participation and empowerment in Russian companies with Western participation. Journal of World Business, 37(3), 180-187.

Michailova, S., and Hollinshead, G. (2011). 9. Negotiating meaning across borders (finally!): Western management training in Eastern Europe. Cross Cultural Management in Practice: Culture and Negotiated Meanings.

Miles, M.B. and Huberman, A.M. (1994). Qualitative Data Analysis: An Expanded Sourcebook, Sage Publications, Newbury Park, CA.

Muratbekova-Touron, M. (2008). From an ethnocentric to a geocentric approach to IHRM: The case of a French multinational company. Cross Cultural Management: An International Journal, 15(4), 335-352.

Myloni, B., Harzing, A. W. K., \& Mirza, H. (2004). Host country specific factors and the transfer of human resource management practices in multinational companies. International Journal of Manpower, 25(6), 518-534.

Neeley, T.B. and Dumas, T.L. (2016), "Unearned status gain: evidence from a global language mandate”, Academy of Management Journal, Vol. 59 No. 1, pp. 14-43.

Nickson, D., Warhurst, C., Lockyer, C., and Dutton, E. (2004). Flexible friends? Lone parents and retail employment. Employee Relations, 26(3), 255-273.

Obeidat, S.M., Mitchell, R. and Bray, M. (2016), "The link between high performance work practices and organizational performance: empirically validating the conceptualization of HPWP according to the AMO model”, Employee Relations, Vol. 38 No. 38, pp. 578-595.

Ohemeng, F.L.K. (2009), "Constraints in the implementation of performance management systems in developing countries: the Ghanaian case", International Journal of Cross Cultural Management, Vol. 9 No. 1, pp. 109-132.

Oppong, N. Y. (2017). Still the Dark Continent? Towards contextual methodological approaches to management development research in foreign multinational firms in Africa. International Journal of Cross Cultural Management, 17(2), 237-256.

Osabutey, E. L. (2013). Exploring foreign direct investment and technology and knowledge transfer issues in Africa. In Cook, G., and Johns, J. (Eds.). The Changing Geography of International Business. Pp. 222335. Palgrave Macmillan, UK.

Osabutey, E. L., and Debrah, Y. A. (2012). Foreign direct investment and technology transfer policies in Africa: A review of the Ghanaian experience. Thunderbird International Business Review, 54(4), 441-456.

Osabutey, E. L., Williams, K., and Debrah, Y. A. (2014). The potential for technology and knowledge transfers between foreign and local firms: A study of the construction industry in Ghana. Journal of World Business 49(4): 560-571.

Parsons, T. (1960). Structure and Process in Modern Societies. New York, NY: Free Press.

Pope, C., Ziebland, S., and Mays, N. (2000). Analysing qualitative data. British Medical Journal, 320(7227), $114-$ 116.

Rosenzweig, P. M., and Nohria, N. (1994). Influences on human resource management practices in multinational corporations. Journal of international business studies, 25(2), 229-251.

Sarabi, A., Froese, F. J., and Hamori, M. (2017). Is inpatriate assignment experience a ticket to the top of a foreign subsidiary? The moderating effect of subsidiary context, Journal of World Business, 52(5), 680-690.

Sartorius, K., Merino, A., and Carmichael, T. (2011). Human resource management and cultural diversity: a case study in Mozambique. The International Journal of Human Resource Management, 22(9), 1963-1985.

Siebers, L. Q., Kamoche, K., and Li, F. (2015). Transferring management practices to China: a Bourdieusian critique of ethnocentricity. The International Journal of Human Resource Management, 26(5), 551-573.

Stake, R. E. (1995). The Art of Case Study Research. Thousand Oaks, CA: Sage.

Suchman, M. C. (1995). Managing legitimacy: Strategic and institutional approaches. Academy of Management Review, 20(3), 571-610.

Sutton, J., and Kpentey, B. (2012). An Enterprise Map of Ghana (Vol. 2). International Growth Centre in association with the London Publishing Partnership. 
Tayeb, M. (1998). Transfer of HRM practices across cultures: an American company in Scotland. International Journal of Human Resource Management, 9(2), 332-358.

Thite, M., Wilkinson, A., and Shah, D. (2012). Internationalisation and HRM strategies across subsidiaries in multinational corporations from emerging economies-A conceptual framework. Journal of World Business, 47(2), 251-258.

Thomas, D.R. (2006), “A general inductive approach for analysing qualitative evaluation data”, American Journal of Evaluation, Vol. 27 No. 2, pp. 237-246.

Trošt, J. K., Škerlavaj, M., and Anzengruber, J. (2016). The Ability-Motivation-Opportunity Framework for Team Innovation: Efficacy Beliefs, Proactive Personalities, Supportive Supervision and Team Innovation. Economic and Business Review, 18(1), 77-102.

United Nations Conference on Trade and Development (UNCTAD). (2013). World Investment Report - Global Value Chains: Investment and Trade for Development (UNCTAD/WIR/2013).

Wanasika, I., Howell, J.P., Littrell, R. and Dorfman, P. (2011), "Managerial leadership and culture in Sub-Saharan Africa", Journal of World Business, Vol. 46 No. 2, pp. 234-241.

Xu, D., Pan, Y., and Beamish, P. W. (2004). The effect of regulative and normative distances on MNE ownership and expatriate strategies (1).Management International Review, 44(3), 285-308.

Yahiaoui, D. (2015). Hybridisation: striking a balance between adoption and adaptation of human resource management practices in French multinational corporations and their Tunisian subsidiaries. The International Journal of Human Resource Management, 26(13), 1665-1693.

Zhao, Z., Anand, J., and Mitchell, W. (2005). A dual networks perspective on inter-organizational transfer of RandD capabilities: international joint ventures in the Chinese automotive industry. Journal of Management Studies, 42(1), 127-160.

Zoogah, D.B., Peng, M.W., \& Woldu, H. (2015). Institutions, resources, and organizational effectiveness in Africa. Academy of Management Perspectives, 29(1), 7-31. 